Publisher homepage: www.universepg.com, ISSN: 2707-4625 (Online) \& 2707-4617 (Print)

https://doi.org/10.34104/ijmms.020.093098

International Journal of Material and Mathematical Sciences UniversePG

Journal homepage: www.universepg.com/journal/ijmms

\title{
Efficient Water Management and Selection of Cooling System for Future NPP in Bangladesh
}

\author{
Md. Rakibul Hasan ${ }^{1}$, K M Rezaur Rahman ${ }^{2}$, Md. Bodhroddoza Shohag ${ }^{1}$, and M. Mezbah Uddin ${ }^{1}$ \\ ${ }^{1}$ Center for Research Reactor, Atomic Energy Research Establishment, Ganakbari, Savar, Dhaka, Bangladesh and \\ ${ }^{2}$ International Affairs Division, Bangladesh Atomic Energy Commission, E-12/A, Agargaon, Sher-e-Bangla Nagar, Dhaka, \\ Bangladesh. \\ *Correspondence: rakibmist@ gmail.com (Md. Rakibul Hasan, Senior Engineer, Center for Research Reactor, Atomic Energy \\ Research Establishment, Ganakbari, Savar, Dhaka, Bangladesh).
}

\begin{abstract}
Water withdrawal today presents a vital issue for Bangladesh to build a new nuclear power plant (NPP) as the country has a deficit in its water resources. It is an issue that may create conflict among the socio-economic activities that require and depend on the water like agriculture that mostly depends on river and ground water. Very recently nuclear power has come into focus during debates on energy generation, often in relation to wider issues such as global warming and climate change. According to Power System Master Plan (PSMP) 2016 of the Government of Bangladesh, it is estimated that a capacity of $7200 \mathrm{MWe}$ of electricity may be generated from nuclear power by 2041 (PSMP, 2016). The government of Bangladesh has already started the construction work of 2400 MWe Rooppur NPP and planning to construct more units of NPPs in the future to fulfill the planning of PSMP 2016. Usually, water is used as a coolant for most of the commercial NPP designed in the present world. In this paper, a study has been performed about the estimation of both the needs for cooling water and other essential systems for a future NPP in Bangladesh using IAEA's Water Management Program (WAMP). Moreover, the selection of cooling systems by evaluating three different criteria: water resource, environment, and economics, has also been performed during this study.
\end{abstract}

Keyword: Cooling system of NPP, IAEA, Water Management Program (WAMP), NPP, and Bangladesh.

\section{INTRODUCTION:}

Water management is an important topic for countries like Bangladesh considering building new NPPs. Good water management addresses the issue of securing water for NPPs at various stages: construction and flushing, cold and hot testing, the condenser cooling operation including the primary coolant makeup system, as well as the safety inventory and release from radioactive liquid waste treatment structure (Moss et al., 1998). In all stages of construction, UniversePG I www.universepg.com operation and maintenance of any NPP, efficient water management is needed. Water use involves two processes that can occur separately or simultaneously: water consumption and water withdrawal.

Water consumption occurs when water either ceases to exist as a liquid, through evaporation (direct evaporation in a cooling tower or increased surface evaporation from the source due to the elevated temperature) or when water is degraded through 
contamination so that it is not fit to be returned directly to its original source.

Withdrawal water means water is removed from a source. It may have consumed and not returned to its origin. The difference between water consumption and water withdrawal is important to any discussion about water use. Normally open loop cooling systems may withdraw significantly more water than recirculating cooling towers, but consume substantially less (Baker, 1988). Other systems may withdraw no water at all, but still consume water, as in reservoir evaporation at a hydroelectric power plant. However, when making such comparisons, differences in cooling water temperature as well as the thermal efficiency of the power plant must be kept in mind.

Water requirements for NPPs may vary, based on the cooling system they involve, the thermal efficiency of the NPP, the need for service water, safety and nonsafety system designs, as well as the waste disposal techniques (Hasan et al., 2020; Mathey, 1990). Selection of site is also a very important parameter in terms of availability of cooling water as well as appropriate atmospheric conditions. These parameters will higher plant efficiencies at lower water withdrawal rates.

Water is required mainly for cooling of NPPs. It is compulsory to carefully choose and design cooling system for NPP. There is a number of cooling processes that can reduce the water consumption rapidly. Cooling water requirements of NPPs exceed the conventional fossil fuel power stations on an average by $20-25$ percent (Khamis and Kavvadias, 2012). Most of the existing NPPs have lower thermal efficiency which is responsible for this as they operate with lower steam pressures and temperatures. These parameters can be varied very slightly as of the limits forced by the common use of zircaloy as a material for fuel cladding and thermal hydraulic considerations [6]. Another limiting condition is the manufacturing capabilities of the main reactor heavy components.

\section{Different methods of cooling used for NPP/Tech- nologies available for cooling systems}

Power plants require dependable access to large amounts of water, mainly for cooling. Normally NPPs use water for cooling in two ways: 1) convey heat to the steam turbines from the reactor core 2) remove and reject excess heat from the internal steam circuit.

If the power plant is next to a large natural water body (Like sea, big river or large inland water body) then the cooling may be achieved simply with a oncethrough cooling system, where large amounts of water are circulated through the condensers and discharged back into water body with less amount of withdrawn.

If such water body does not exist nearby, the cooling may have carried out by passing water throughout the condenser unit and then through a cooling tower, where an up breeze of air through water droplets cools the water. Normally an on-site water body may be good enough for this.

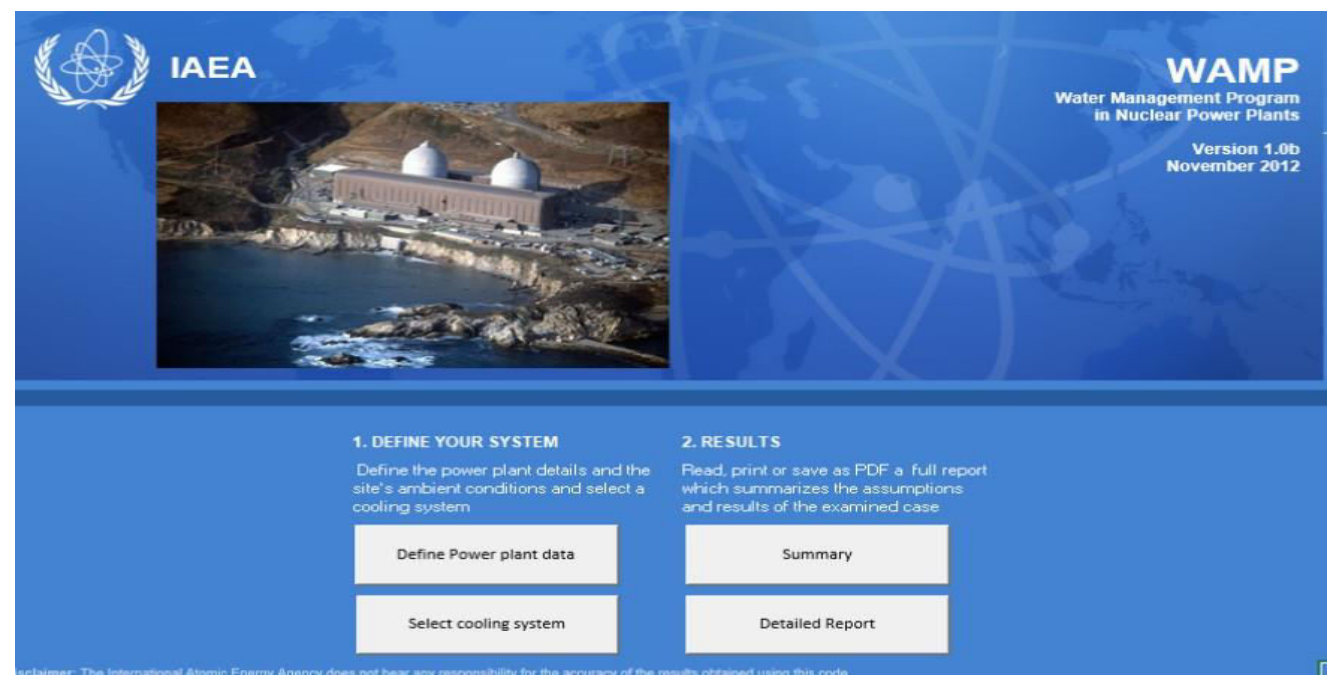

Fig 1: WAMP user interface. 
Table 1: Distribution of cooling systems in current operating NPPs

\begin{tabular}{|c|c|c|c|}
\hline $\begin{array}{c}\text { Once-through } \\
\text { cooling }\end{array}$ & $\begin{array}{c}\text { Closed } \\
\text { cycle }\end{array}$ & $\begin{array}{c}\text { Sea/Lake/ } \\
\text { River water }\end{array}$ & $\begin{array}{c}\text { Cooling } \\
\text { tower }\end{array}$ \\
\hline $45 \%$ & $15 \%$ & $14 \%$ & $26 \%$ \\
\hline
\end{tabular}

\section{METHODOLOGY:}

Water Management Program (WAMP) is used for this study. The IAEA has developed and released the WAMP, which is freely available to all Member States which may be used for the estimation of water needs in NPPs especially for water cooled NPPs. The program estimates both the needs for cooling water and other essential systems.

Following flow chart shows a brief idea about different cooling types available presently -

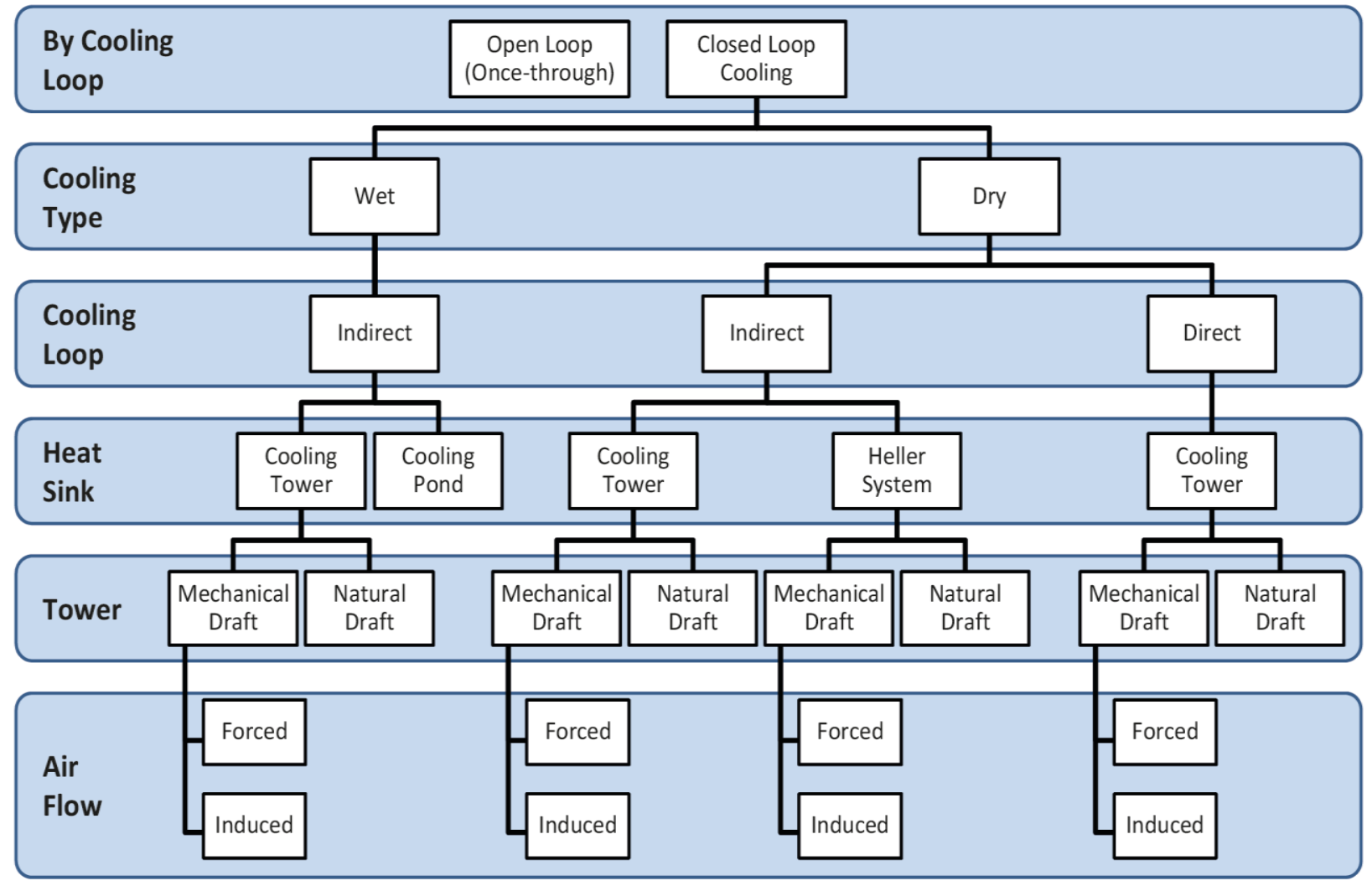

Fig 2: Different types of cooling system.

\section{Study of cooling system for the proposed site}

For the proposed site, the following NPP parameters have been chosen, considering that Bangladesh is going to construct large size NPP in future. Parameters chosen are shown on Table 2.

Table 2: Assumed Power Plant Specifications and Site conditions

\begin{tabular}{|l|l|}
\hline \multicolumn{2}{|c|}{ Power Plant Specifications } \\
\hline Type & Light Water Reactor \\
\hline Reactor electric capacity & $1199 \mathrm{MWe}$ \\
\hline Reactor thermal capacity & $3600 \mathrm{MWth}$ \\
\hline Reference efficiency & $33 \%$ \\
\hline Rejected heat & $2380 \mathrm{MWth}$ \\
\hline Coolant flow rate through reactor & $23.88 \mathrm{~m}^{3} / \mathrm{s}$ \\
\hline
\end{tabular}




\begin{tabular}{|c|c|}
\hline & Site conditions \\
\hline Location & River/Inland \\
\hline Dry bulb temperature & $28^{\circ} \mathrm{C}$ \\
\hline Wet bulb Temperature & $23.6^{\circ} \mathrm{C}$ \\
\hline Relative Humidity & $70 \%$ \\
\hline Surface water temperature & $25{ }^{\circ} \mathrm{C}$ \\
\hline River flow & $95 \mathrm{~m} 3 / \mathrm{s}$ \\
\hline Average wind velocity & $3.05 \mathrm{~m} 3 / \mathrm{s}$ \\
\hline
\end{tabular}

After considering the above mentioned specification, the cooling water requirements were calculated using WAMP software. The results are tabulated below:

Table 3: Simulation result for water withdrawal and water consumption for different cooling systems

\begin{tabular}{|c|c|c|}
\hline Cooling System Type & $\begin{array}{c}\text { Water Withdrawal } \\
\left(\mathrm{m}^{3} / \mathrm{s}\right)\end{array}$ & $\begin{array}{c}\text { Water Consumption } \\
\left(\mathrm{m}^{3} / \mathrm{s}\right)\end{array}$ \\
\hline Once Through & 58.12 & 0.79 \\
\hline Once Through (Cooling Pond) & 58.12 & 0.79 \\
\hline Close Loop with Cooling Pond & 0.67 & 0.45 \\
\hline Wet Cooling (Mechanical Draft) & 1.54 & 1.05 \\
\hline Wet Cooling (Natural Draft) & 1.58 & 1.13 \\
\hline Hybrid Plume Abatement & 1.57 & 1.07 \\
\hline
\end{tabular}

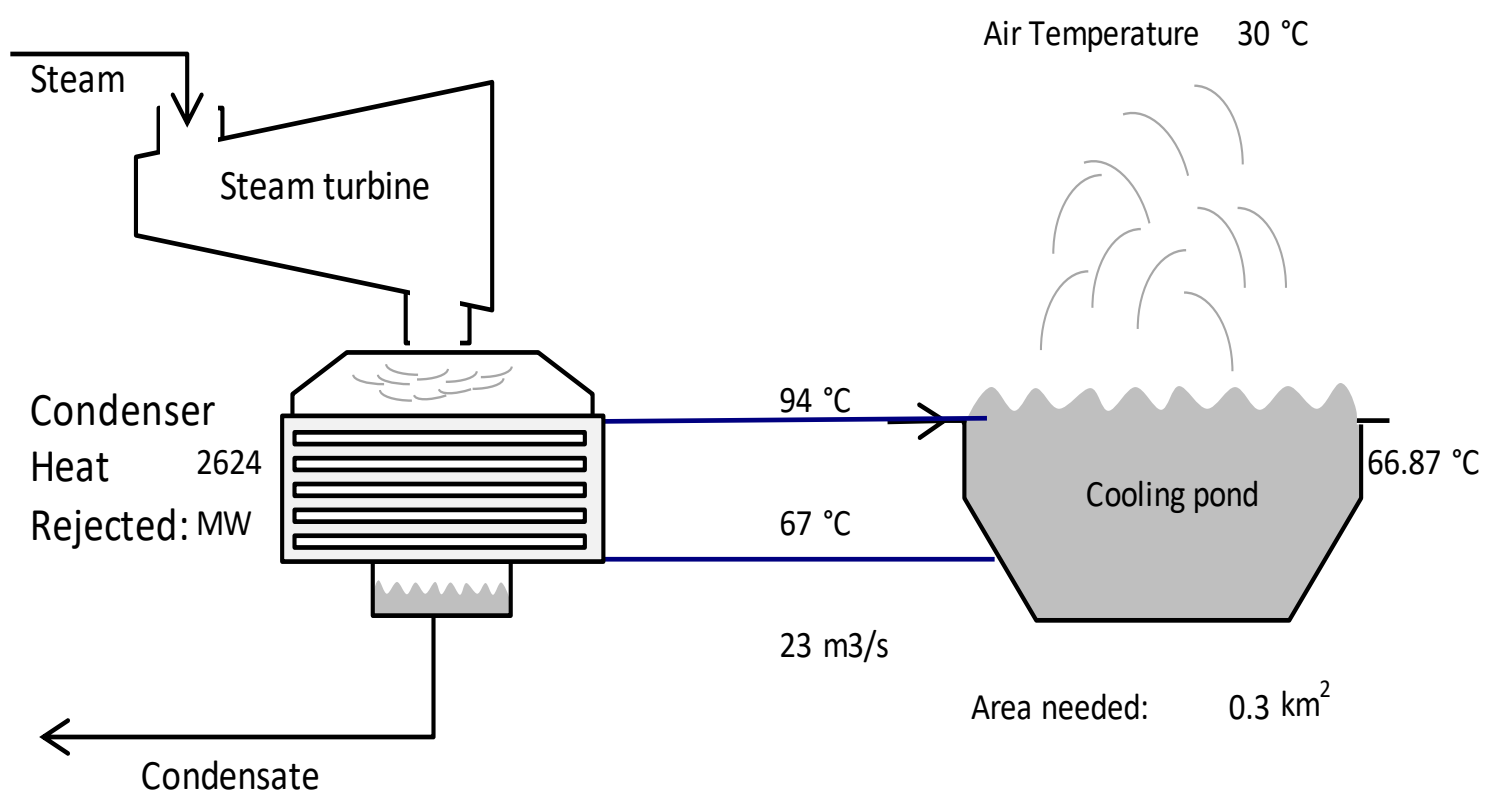

Fig 3: Close Loop cooling system with cooling Pond simulation result. 
It is found that once through cooling system required highest amount of water for cooling and close loop with cooling pond required lowest amount of water.

Table 4: Cost estimation for cooling systems

\begin{tabular}{|c|c|c|}
\hline Cooling System Type & Capital Cost (M\$) & Operating Cost (M\$/Yr) \\
\hline Once Through & Base Cost & Base Cost \\
\hline Once Through (Cooling Pond) & 0.00 & Base Cost \\
\hline Close Loop with Cooling Pond & 84.4 & 15.5 \\
\hline Wet Cooling (Mechanical Draft) & 47.2 & 5.4 \\
\hline Wet Cooling (Natural Draft) & 82.7 & 30.3 \\
\hline Dry Cooling(Air Condenser) & 135.9 & 21.3 \\
\hline Hybrid Plume Abatement & 129.9 & \\
\hline
\end{tabular}

Table 5: Environmental impact of different cooling systems

\begin{tabular}{|c|c|c|c|c|}
\hline $\begin{array}{l}\text { Environmental Impact } \\
\text { Type }\end{array}$ & Visual Impact & Plume & $\begin{array}{l}\text { Thermal } \\
\text { Pollution }\end{array}$ & Air Pollution \\
\hline Once Through & & & $\sqrt{ }$ & \\
\hline Once Through (Cooling Pond) & $\sqrt{ }$ & & & \\
\hline Close Loop with Cooling Pond & $\sqrt{ }$ & & & \\
\hline Wet Cooling (Mechanical Draft) & $\sqrt{ }$ & $\sqrt{ }$ & $\sqrt{ }$ & \\
\hline Wet Cooling (Natural Draft) & $\sqrt{ }$ & $\sqrt{ }$ & $\sqrt{ }$ & \\
\hline Dry Cooling (Air Condenser) & $\sqrt{ }$ & & & $\sqrt{ }$ \\
\hline Hybrid Plume Abatement & $\sqrt{ }$ & & $\sqrt{ }$ & $\sqrt{ }$ \\
\hline
\end{tabular}

Table 4 shows the capital and operation cost of different cooling system analyzed by WAMP software.

Table 5 shows the environmental impacts (Visual Impact, Plume, Thermal Pollution, Air Pollutions etc.) of different cooling systems

\section{RESULTS AND DISCUSSION:}

To dissipate the rejected heat $\left(2380 \mathrm{MW}_{\mathrm{t}}\right)$ from the reactor, flow rate of coolant at the condenser side should be $23 \mathrm{~m}^{3} / \mathrm{s}$ or more. From the simulation result obtained from WAMP, it is found that close loop cooling system with cooling Pond can ensure $23 \mathrm{~m}^{3} / \mathrm{s}$ coolant flow rate at the condenser side. This system has the lowest water withdrawal and water consum-

UniversePG I www.universepg.com ption rate $\left(0.67 \mathrm{~m}^{3} / \mathrm{s}\right.$ and $0.45 \mathrm{~m}^{3} / \mathrm{s}$ respect-ively) in comparison with the other systems.

This system has a higher establishment cost in compare with wet cool system but it has no operating cost at all (only base cost). The system has almost no environmental impact and very much favorable for a country like Bangladesh. So; close loop cooling system with cooling pond may be a good option for future NPP in Bangladesh with respect to the selected site conditions.

\section{CONCLUSION:}

As a new comer country in the field of nuclear power plant, Bangladesh need to consider the environmental impact as well as the cost effectiveness of the cooling 
system for NPPs. By considering both criteria it can be said that close loop cooling system with cooling pond can be a good option for future NPP in Bangladesh.

\section{ACKNOWLEDGEMENT:}

Sincere acknowledgement to the colleagues of Center for Research Reactor, AERE to support for the successful completion of the present study.

\section{CONFLICT OF INTERESTS:}

The authors declare no conflicts of interest.

\section{REFERENCES:}

1. Baker, N.T. (1988). Management techniques for site-specific water-use information in Symposium on Water Use data for Water Resources Management, Tucson, Ariz., 1988, Proceedings: American Water Resources Association, TPS-88-2, $872 \mathrm{p}$.

2. Efficient Water Management in Water Cooled Reactors, International Atomic Energy Agency, Nuclear Energy Series No. NP-T-2.6, IAEA, Vienna (2012), Pages 116. https://www-pub.iaea.org/MTCD/Publications/ PDF/P1569_web.pdf
3. Khamis I., and Kavvadias C., (2012). Trends and challenges toward efficient water management in nuclear power plants, Nuclear Engineering and Design, 248, Pages 48-54.

4. Mathey, Sharon B. (1990). National water information system user's manual, v. 2, chapter 5, water use data system Part 1, Site Specific Water-use Data System (SSWUDS): Reston Va., U.S. Geological Survey OpenFile Report 90-198, Version 90.2, variously paged.

https://pubs.usgs.gov/of/1990/0198/report.pdf

5. Moss, D.; Williams, N.; Hall, D.; Hargis, K.; Saladen, M.; Sanders, M. et al. (1998). Elimination of liquid discharge to the environment from the TA-50 Radioactive Liquid Waste Treatment Facility, Pp. 1-67.

https://digital.library.unt.edu/ark:/67531/metadc $\underline{708040 /}$

6. Power System Master Plan (PSMP), (2016). Bangladesh Energy Regulatory Commission, July 2017. Pp. 1-82.

https://drive.google.com/file/d/1GLL4en1oPUI2 zb5RYLQFt5-9Ko7o2a m/view

Citation: Hasan MR, Rahman KMR, Shohag MR, and Uddin MM. (2020). Efficient water management and selection of cooling system for future NPP in Bangladesh, Int. J. Mat. Math. Sci., 2(6), 93-98. https://doi.org/10.34104/ijmms.020.093098 @ @ 